\title{
Islamic Values and Sasak Local Wisdoms: The Pattern of Educational Character at NW Selaparang Pesantren, Lombok
}

\author{
Nashuddin \\ Universitas Islam Negeri (UIN) Mataram \\ Email: nashuddin88@gmail.com
}

\begin{abstract}
This study aims to analyze the relevance of Islamic values to the local cultural values of Sasak Lombok community, and the role of pondok pesantern (Islamic boarding schools) in integrating both of them in building student character in educational practices. This is important because there is a phenomenon that certain religious group contradistinguish between Islam and local traditions. Even in many cases local traditions are considered to lead to heresy and novelty. Through field studies with a qualitative approach, and applying Thomas Lickona's theory as the theoretical framework, this study argues that substantively, Islam and local culture have relevance to the local traditions of Sasak society. In this context, pondok pesantren have a strategic role that successfully integrates the two. On the one hand, pondok pesantren grows from the community itself, and on the other hand, it is also an Islamic educational institution. This position makes it possible for pondok pesantren to maintain the character of the santri by integrating local culture and religion as the basis for character education. Practically, the pattern of character development based on the wisdom of Sasak culture is carried out through three stages: moral knowing, moral feeling, and moral action. These three stages succeeded in bringing together Islam and the local tradition of Sasak in educational practice.
\end{abstract}

Keywords: Islam, Pondok Pesantren, local culture, character education

DOI: https://doi.org/10.20414/ujis.v24i1.392

\section{Introduction}

IN THE LAST few decades, character education has become one of the most interesting topics in the discussion about education in Indonesia. This might be due to the fact that moral crisis is a 
serious problem in the country, which has been exposed by mass media. In general, the degradation of character can be seen with the rising cases of corruption, drugs, drinking, robbery, mode of fraud and even murder. The other cases include student communal brawl and bullyings. To overcome the problem, the government applies character education as a solution to fix those quite alarming problems. Not only limited to the school and family environment, character education is also integrated in the scope of religion. Since Indonesian society is a religious country. ${ }^{1}$

Character education covers a very broad base. Education experts in Indonesia, find new alternatives in shaping the character of the nation on the basis of local wisdom. Substantially, local wisdom is a manifestation of the values that apply in a society and are believed to be true and become a reference in the daily behavior of the local community. One of the nation's Islamic educational institutions, namely pondok pesantren, still applies character education based on local wisdom. Thomas Lickona, quoted from Aynur Pala, perceives character education as a conscious effort aimed at bringing about the nature of goodness. Awareness is a key to education that students do not necessarily have good character directly. However, students need role models and good advice in an effort to grow the good character. ${ }^{2}$ The aspirations of teachers and people involved in education naturally want to see children who are admired have good character, therefore, they need to introduce and teach the criteria of good characters. ${ }^{3}$

There is one aspect that has not received sufficient attention in the process of character building. It is local traditions. So far, character education has been based more on universal

1 Alfaqih, Strategi Pendidikan Karakter: Mempertimbangkan Tradisi Profetik (Mataram: Larispa, 2011), 31.

2 Aynur Pala, "The Need for Character Education," International Journal of Social Sciences and Humanity Studies 3, no. 2 (2011): 25, http://www.sobiad.org/eJOURNALS/journal_IJSS/arhieves/2011_2/aynur_pala.pd f.

${ }^{3}$ Andrew J. Milson and Lisa M. Mehlig, "Elementary School Teachers' Sense of Efficacy for Character Education," The Journal of Educational Research 96, no. 1 (2002): 47, accessed June 18, 2019, https://www.jstor.org/stable/27542411. 
humanitarian and religious values, but not many experts have explored further the richness of local traditions as the basis for character building. Even at the same time, as Saparudin ${ }^{4}$ and Faizah ${ }^{5}$ found, there is a phenomenon that certain religious group contradistinguish Islam and local traditions. Local traditions are considered to bring heresy and religious innovation among the people. This study argues that substantively, Islam and local culture are relevance to the local tradition values. It will show how Islamic boarding school (pondok pesantren) has managed to integrate Islam and local wisdom. As an Islamic educational institution embedded within a society, pesantren may grow in and develop along with the surrounding communities.

This study aims to analyze the relevance of Islamic values to the local cultural values of the Sasak in Lombok, in eastern Indonesia and examines the role of pondok pesantren in integrating Islam and local values in building students' character in educational practices. This article is the result of a field study conducted at the Pondok Pesantren Nahdhatul Wathan (NW) Selaparang Kediri, West Lombok. This Islamic school is known as one pesantren that consistently uphold the Sasak tradition and integrate them in the development of the character of its students. Operationally, this study uses Thomas Lickona's theory which formulates that the pattern of character development is carried out through three stages: moral knowing, moral feeling, and moral action. These three stages succeeded in bringing together Islam and local Sasak traditions in the practice of education in this local Islamic educational institution.

\section{Muslims and Local Traditions of Sasak}

Each community has its own local wisdom grounded from their respective cultures. In general, local wisdom can be understood as local ideas that are wise, full of wisdom, good value

${ }^{4}$ Saparudin, "Salafism, State Recognition and Local Tension: New Trends in Islamic Education in Lombok," Ulumuna 21, no. 1 (June 30, 2017): 82-87, accessed June 10, 2019, https://ulumuna.or.id/index.php/ujis/article/view/68.

5 Faizah, "Pergulatan Teologi Salafi dalam Maenstream Keberagamaan Masyarakat Sasak," Ulumuna 16, no. 2 (December 2012): 393-399, accessed June 17, 2019, http://ejurnal.iainmataram.ac.id/index.php/ulumuna/article/view/183. 
and embedded and followed by members of the community. Local wisdom is an unwritten regulation which becomes a reference for the members of the community which covers all aspects of life: (1) rules governing relations between human beings such as in social interactions, both individuals and groups, relating to the hierarchy in governance and custom, rules of inter-clan marriage, and manners in daily life; (2) rules regarding the relationship between humans and nature, animals and plants which are aimed at conserving nature; (3) rules concerning human relations with the unseen, for example God and supernatural spirits. Not all of theses aspects are used as the focus in this research activity, only aspects relating to social-economic interactions between individuals and between groups, especially in socio-economic-religious life. ${ }^{6}$

Lombok Island is often used as a model for the diversity of religions, ethnicities, and languages. Sasak Muslims are native to the island of Lombok with a majority of 90 percent according to the 2015 census with the number of inhabitans around 2,200,368. ${ }^{7}$ While other ethnic minority groups are Balinese, Sumbawa, Bugis, Javanese, Arabic, and Chinese contributing to Lombok's overall cultural pluralism. Sasak claims the island of Lombok as gumi sasak (the land of sasak). ${ }^{8}$ From the aspect of religion, Muslims make up $96.4 \%$ of the total population, Hinduism 2.5\%, Buddhism 0.5\%, Protestant Christianity $0.4 \%$, and Catholic Christianity $0.2 \%{ }^{9}$

At the beginning of the introduction of Islam in the 16th centur, ${ }^{10}$ the Sasak adhered to a pattern of syncretism, a mixture of Austronesian beliefs and Islam which was the form of Islamic

${ }^{6}$ Erwan Baharudin, "Kearifan Lokal, Pengetahuan Lokal Dan Degradasi Lingkungan," Forum Ilmiah 7, no. 1 (2010): 13, accessed August 18, 2019, https://ejurnal.esaunggul.ac.id/index.php/Formil/article/view/1317.

7 Badan Statistik Pemprov NTB, Nusa Tenggara Barat Dalam Angka Tahun 2015, n.d., 71.

8 Erni Budiwanti, "Balinese Minority Versus Sasak Majority: Managing Ethno-Religious Diversity and Disputes in Western Lombok," Heritage of Nusantara: International Journal of Religious Literature and Heritage 3, no. 2 (February 12, 2015): 235, accessed June 18, 2020, http://jurnallektur.kemenag.go.id/ index.php/heritage/article/view/11.

${ }^{9}$ Badan Statistik Pemprov NTB, Nusa Tenggara Barat, 71.

${ }^{10}$ Sven Cederroth, The Spell of The Ancestors and The Power of Mekkah A Sasak Community on Lombok (Sweden: Acta Universitatis Geyheburgensis, 1981), 32. 
community of Sasak people in the early days. ${ }^{11}$ This pattern at a later stage proceeds to become Wetu Telu, a type of syncretic religion between Animism, Hindu and Islamic beliefs. ${ }^{12}$ Even though they claim to be Muslims, they continually worship ancestor spirits, various spirit gods and others in their own way. ${ }^{13}$ This condition allows Islam to be relatively easy to be accepted by Sasak society, because conceptually the teachings of Islam do not threaten the structure and local beliefs of Sasak. ${ }^{14}$ Second, the Islamic propaganda pattern adopted reflects a flexible strategy that tends to be tolerant to local culture. ${ }^{15}$

Based on this background, the community has a rich treasury of tradition and high religiosity at the same time. In the tradition of the Sasak there are a variety of customary processional activities developing in the the community which are governed by awigawig or local rules. First is adat gama (religious custom), which refers to religious teachings and guidance, such as adat nikahang (marriage custom), adat nyunatang (circumcision custom), adat ngurisang (haircut custom for the baby) and others.

Second is adat luir gama is a ceremony held in connection with the occurrence of long drought or excessive rain. In the implementation of luir gama customs, there are various types of cultural traditions that are still carried out in several areas of Lombok island including the tradition of ngayu-ayu, basentulak and various other types of ceremonies. Ngayu-ayu means asking for welfare and metulak is returning or better known as tolak bala (stem

${ }^{11}$ John Ryan Bartholomew, Alif Lam Mim Kearifan Masyarakat Sasak, trans. Imron Rosyidi (Yogyakarta: Tiara Wacana, 2001), 95.

${ }^{12}$ Mohamad Abdun Nasir, "Conflict, Peace, and Religious Festivals: MuslimHindu-Christian Relations on the Eastern Indonesian Island of Lombok," Interreligious Studies and Intercultural Theology 4, no. 1 (April 14, 2020): 102-123, accessed April 18, 2020, http://ojs3.equinoxpub.com/ISIT/article/view/17625.

${ }^{13}$ Saparudin, "Gerakan Keagamaan dan Peta Ideologis Pendidikan Islam di Lombok," MIQOT: Jurnal Ilmu-ilmu Keislaman 42, no. 1 (August 25, 2018): 224-227, accessed June 18, 2020, http://jurnalmiqotojs.uinsu.ac.id/index.php/jurnalmiqot/ article/view/506.

${ }^{14}$ Bartholomew, Alif Lam Mim, 95.

${ }^{15}$ Saparudin, "Gerakan Keagamaan dan Peta Ideologis Pendidikan Islam di Lombok," 225-227. 
calamity). This ceremony is intended to reject pests, diseases, disasters and evil spirit disorders.

Third is adat tapsila, which is a tradition related to the concept of attitude or behavior in social life. Forth is adat urip, that is a series of traditions from the time of pregnancy to the born of the baby. These traditions consist of bretes / besoq tian which is done in the $7^{\text {th }}$ months of pregnancy and praq api which is a process of giving name to the baby after the $7^{\text {th }}$ days of birth.

Fifth is adat pati or dead custom. It is a tradition related to ritual where a member of the community dies. In the tradition of gawe pati there are several types of events based on the time of the burial ceremony. The series of death ceremony begins with the nelung ceremony, which is a ceremony after 3 days after death, mituq (seventh days after the death), nyiwaq (the ninth day), metang puluh (fortieth days), nyatus (the hundredth day), even until the thousandth day after the death. ${ }^{16}$

\section{Wisdom Values of Sasak Local Traditions and the Relevance with Islam}

Those five forms of custom processes developed in Sasak community and in a small unit of society, such as Islamic school. Pondok Pesantren NW Selaparang Kediri takes one of them (adat tapsila) as a social system developed in pondok pesantren to preserve local culture. Adat tapsila is a tradition of Sasak people which is related to the principles, norms and rules of social organization which are tangible into a social system and are a habit of daily behavior in relationships. ${ }^{17}$ In pondok pesantren, adat tapsila custom is manifested in a form of local wisdom, namely, berembuq, besemeton, alus base, tertip tapsile, and reme.

16 I. Gede Yudarta and I. Nyoman Pasek, "Revitalisasi Musik Tradisional Prosesi Adat Sasak Sebagai Identitas Budaya Sasak," Segara Widya : Jurnal Hasil Penelitian dan Pengabdian Masyarakat Institut Seni Indonesia Denpasar 3 (October 17, 2015): 372-374, accessed May 18, 2019, https://jurnal.isidps.ac.id/index.php/segarawidya/article/view/175.

17 Lestari, “Islam Nusantara Corak Spiritualitas Pribumi,” Jurnal Elkatarie : Jurnal Ilmu Pendidikan dan Sosial 1, no. 02 (August 19, 2019): 34, accessed August 29, 2019, http://ejournal.kopertais4.or.id/sasambo/index.php/elkatarie/article/ view/3610. 
The application of adat tapsila in pondok pesantren aims to make the life of the students become focused and can create a harmonious atmosphere, in which there are democratic values, discipline, brotherhood, love of the motherland, peace, and care for the environment. These values are the guideline for every student in the pondok pesantren. Here, pondok pesantren prove itself capable of understanding local culture through an acculturativecontextual approach. It is said to be acculturative-contextual because pesantren prefer to compete side by side with no competition with the developing local culture, then slowly complement it back into local wisdom that symbolically represents the spiritual atmosphere the local community. ${ }^{18}$

Here are some forms of local wisdom developed in Pesantren NW Selaparang Kediri, Lombok:

Berembuq: Building Democratic and Discipline Attitude of Students

In solving problems among Sasak community, there is a term called berembuq (deliberation). The term berembuq teaches that in dealing with problems it is recommended to be resolved by sharing, so that problems can be solved together. There is a common saying among sasak people related to this, "Mun arak masalah te seleseang isik berembuq" meaning that if there is a problem, we solve it by deliberating. ${ }^{19}$

Deliberation is very important in creating regulations in any society. Every developed country that wants to create security, peace, happiness, and success for its people always holds the principle of deliberation. This is in line with the teaching of Islam which obligates the importance of deliberation. ${ }^{20}$

Likewise, the deliberation which is still being implemented in pondok pesantren in the context of creating a disciplined attitude in

${ }^{18}$ Nurul Fauziah, “Perkembangan Pendidikan Islam Dan Kearifan Lokal Di Indonesia," AL-FURQAN 6, no. 2 (February 28, 2018): 65, accessed June 11, 2019, http://ejournal.kopertais4.or.id/sasambo/index.php/alfurqan/article/view/3267.

19 Niswatul Hasanah, "Nilai Budaya Ungkapan Tradisional Pergaulan Keseharian Masyarakat Sasak," Jurnal Mabasindo 1, no. 2 (2017): 227.

20 Azis Taufik Hirzi, "Komparasi Ringkas Antara: Demokrasi Ala Barat dengan Musyawarah dalam Islam," MIMBAR: Jurnal Sosial dan Pembangunan 21, no. 2 (June 13, 2005): 254-255, accessed June 19, 2018, https://ejournal.unisba.ac.id/index.php/mimbar/article/view/176. 
the form of rules and sanctions for students who violate rules. The process of deliberation is carried out democratically, where the head of the pondok pesantren does not necessarily impose a sanction or regulation unilaterally but by way of jointly asking for opinions from all levels of management in the pondok pesantren. The democratic attitude of the meeting indicates that every coordinator in the management has the right to express his aspirations openly.

According to Soekanto, quoted from Ezi Hendri, et al., an interaction and enthusiastic presence can be used to measure the effectiveness of deliberation approach. ${ }^{21}$ The attitude of deliberation at pondok pesantren in enhancing democratic attitudes and building a disciplined attitude of the students is in accordance with the verses of the Qur' an chapter 3 (Ali-Imran) verse 159:

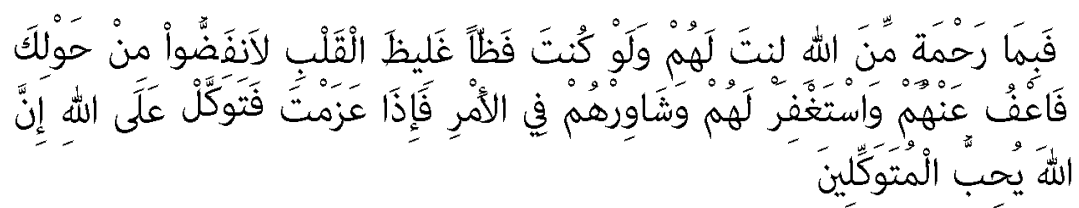

So by mercy from Allah, [O Muhammad], you were lenient with them. And if you had been rude [in speech] and harsh in heart, they would have disbanded from about you. So pardon them and ask forgiveness for them and consult them in the matter. And when you have decided, then rely upon Allah. Indeed, Allah loves those who rely [upon Him]. ${ }^{22}$

The verse of the Qur'an above shows that deliberation is in harmony with the context of the Qur'an and Assunah to motivate the participation of all parties to determine and organize the life of the santri as a whole in creating an attitude of discipline. The head of pondok pesantren asks the opinion of the coordinator of each division directly related to the problems faced by the students. The requirements of the consultation system in dealing with problems in pondok pesantren are passed freely, fairly, and sincerely.

21 Ezi Hendri, Ninuk Purnaningsih, and Amiruddin Saleh, "Analisis Efektivitas Musyawarah Perencanaan Pembangunan," Jurnal KMP (Jurnal Komunikasi Pembangunan) 12, no. 2 (November 10, 2014): 61, accessed May 12, 2019, http://journal.ipb.ac.id/index.php/jurnalkmp/article/view/8656.

${ }^{22}$ Ar-Rasyid, Al-Qur'an Mushaf Terjemah Tanpa Ta'wil (Jakarta: Insan Media Pustaka, 2012), 71. 
Besemeton: Building Friendly Attitudes and Social Care

Linguistically, besemeton is taken from the root word semeton which means brother/sister. ${ }^{23}$ In Sasak culture terminology, it symbolizes the concepts that build social behavior of Sasak tribe community such as the concepts of collectivity and unity. ${ }^{24}$ This character symbolizes a sense of friendship between people. With the concept of besemeton, Sasak people can help each other, be friendly, and love each other.

The concept of besemeton as a kinship system applied by pondok pesantren for students has the same goal, namely, tafaqquh fì al-din in order to deepen religious knowledge. This is confirmed by the function of the hostel as a place to live for the students. Each hostel provided by pesantern aims to foster a sense of brotherhood and saling ajini. ${ }^{25}$ Even when eating together (Sasak: begibung), there is a feeling of brotherhood among the students so they can feel the sad and happiness together. The foundation of besemeton attitude applied by pondok pesantren NW Selaparang Kediri gave birth to a value of friendly attitude which was highly recommended by the Prophet Muhammad SAW in the hadith which reads as follows:

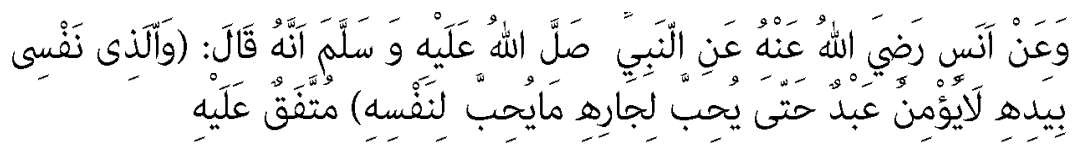

Narrated by Anas R.A from Rasulullah SAW, the Prophet said, "For the sake of my soul in His grasp, does not believe a servant so that he loves his brother as he loves himself" ${ }^{26}$

In addition to fostering a sense of brotherhood and saling ajinin (mutual respect), besemeton attitude contains enormous benefits among the relationship of the students in pondok pesantren NW Selaparang Kediri in an Islamic nuance and gave birth to a

${ }^{23}$ Lalu Muhammad Azhar, Kamus Bausastra Sasak Indonesia-Indonesia Sasak (Klaten: Macanan Jaya Cemerlang, 1997), 184.

${ }^{24}$ Lalu Ratmaja, Bahan Ajar Muatan Lokal Budaya Sasak untuk SMP/MTs Kelas IX (Lombok: Gumi Sasak, 2011), 97.

${ }^{25}$ Saling ajinin in Sasak custom means respect each other in friendship and relationship. See Lalu Ratmaja, Bahan Ajar Muatan Lokal Budaya Sasak untuk SMP/MTs Kelas VIII (Lombok: Gumi Sasak, 2011), 79.

26 Aḥmad ibn 'Alī Ibn Ḥajar al-Asqalānī, Bulūgh al-Marām min Adillati alAhkām (Semarang: Karya Putra, n.d.), 331. 
system that contains social care values in the local cultural frame of the Sasak Tribe such as, saling perasaq, ${ }^{27}$ saling peringet ${ }^{28}$, and saling sauq. ${ }^{29}$

This besemeton attitude is not only applied when the students are still active living in pondok pesantren, but it will give birth to an awareness that, santri as a social being will continue to feel a sense of brotherhood, to the next stage after becoming an alumni, by tightening the silaturrahmi (relationship) among their friends. This is called salingwales/bales in sasak customs..$^{30}$

\section{Base Alus: Instilling the Love of the Motherland to the Santri}

Language is a major component in communication in addition to other components such as gestures, tone, and so on. Without language there will never be verbal communication. Thus, the importance of language as a communication tool makes some linguists state that language is as important as breathing. ${ }^{31}$

In general, for most people in Lombok, only two forms of language are known in daily communication, namely the so-called Sasak biase / jamaq or aok-ape (yes-what) and Sasak alus or tiangenggih (I-yes). The highest level of Sasak language, which is called kaji-meran (I-yes), is only used by the datu-raden (nobel famiy). The classification is based on the social stratification of the Sasak people as aristocrats or menak/perwangsa and not nobles or not menak/perwangsa. The factors determining the choice of the form of language used, as in other languages, are age, social status,

27 Saling perasaq means sharing food to each other, including to other people from different religion. See Ratmaja, Bahan Ajar, 79.

${ }^{28}$ Saling peringet means remind each other among friends/relatives honestly for the sake of goodness and brotherhood. Ibid., 80 .

29 Saling sauq means trust each other in communication and friendship especially among friends from sasak or among sasak people with non-sasak people. Ibid.

30 Saling wale/bales means visit someone who has visited you or reply the good things done to you, This occurs due to the close relationship among people from the same tribe, other tribes or even religions. Ibid..

31 Ni Wayan; Sartini, "Bahasa Pergaulan Remaja: Analisis Fonologi Generatif," Mozaik: Jurnal Ilmu Humaniora 12, no. 2 (December 2012): 122. 
education, level of familiarity, conversation situations, type of conversation (formal/informal). ${ }^{32}$

The use of the Sasak alus language in Islamic boarding schools is very much emphasized in interacting with each other without having to look at social status, age, and levels of education because basically santri have the same status in pondok pesantren. They are all viewed as people who are seeking knowledge. In daily communication with fellow students, teachers, and other people around pondok pesantren, santri are expected to use Sasak alus language or at least if they do not master the use of Sasak alus language they can use Sasak jamaq/biase (ordinary Sasak). However, they are not allowed to use abusive language such as calling someone as "kamu" (you) because this is considered rude in Sasak language.

Lately, there has been a tendency for a shift in the use of mother tongue by the Sasak tribe, from the mother tongue of Sasak language to the Indonesian mother tongue. This tendency occurs not only in urban areas but also in rural areas. This suggests that without a political attitude from the local government, this shift in the use of mother tongue will continue. In the meantime, efforts to maintain Sasak language must be carried out immediately. ${ }^{33}$ One of the strategies adopted in preserving Sasak language carried out by pondok pesantren as an act of raising the love to the motherland is by setting a set of rules for example, by memorizing Sasak language vocabulary and applying it in everyday communication.

\section{Tertip Tapsile: Expression of Peaceful Love}

Tertip tapsile in Sasak language comes from two words namely tertip and tapsile. Tertip means that if you have arranged your life, it will definitely be orderly. Whereas, tapsile is taken from the

32 Sudirman Wilian, "Tingkat Tutur dalam Bahasa Sasak dan Bahasa Jawa," Wacana 8, no. 1 (April 1, 2006): 35, accessed June 19, 2019, http://wacana.ui.ac.id/ index.php/wjhi/article/view/245.

33 Ahmad Sirulhaq, "Konsep Dasar Standarisasi Bahasa Sasak: Ke Arah Kebijakan Pembelajaran dan Pemertahanan Bahasa Sasak di Lombok" (Presented at the International Seminar Language Maintenance and Shift. ISSN: 2088-6799, Hotel Pandanaran Semarang, 2011), 173, accessed September 19, 2019, http://lamas.undip.ac.id. 
word besile which means the levels of behavior must be obeyed proportionally both in the placement of language and good behavior as a tribute to someone. ${ }^{34}$ This custom of courtesy is emphasized by Sasak people in their daily interactions to build up manners in their relationships with others.

Pondok pesantren strongly emphasizes the concept of tertip tapsile as a social system that is applied both in pondok pesantren environment and in the community in managing love for peace among the santri by conversing and behaving politely. This has been established and even confirmed through the rules that apply in pondok pesantren with the aim of maintaining good relations between fellow santri, teachers, and the surrounding community. The concept of tertip tapsile is in harmony with the saying of the Prophet Muhammad about the importance of polite manners:

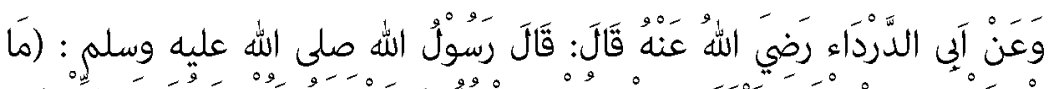

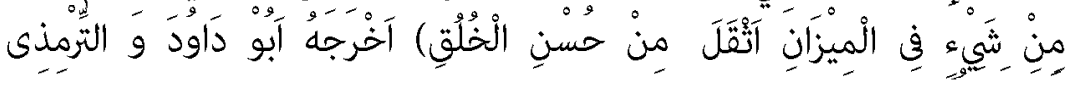
وصحمه.

From Abu Darda 'RA said, the Prophet said: there is no good deed in a scale that is better than good morals. ${ }^{35}$

The essence of the application of tertip tapsile in pondok pesantren is emphasized in the tindih attitude or the expression of caution in speaking and acting. It can also be interpreted as an personality that has the sincerity to defend a truth, goodness, beauty and nobleness. It can also be interpreted as the personality of an obedient person. ${ }^{36}$

The term tindih teaches that in associating with others, it is necessary to maintain ethics in speaking and acting so as not to offend others. This term is frequently used by Sasak people as an expression of someone who has a manut (obedient) attitude to the

34 Setiahati, "S2 (Bukti Cinta Suku Sasak)," Pesona Budaya Pulau Seribu Masjid, December 21, 2017, accessed March 23, 2020, http://setia28.blogspot.com/ 2017/12/s2-bukti-cinta-suku-sasak.html.

35 al-Asqalānī, Bulūgh al-Marām, 342.

${ }^{36}$ Hasanah, “Nilai Budaya Ungkapan," 227. 
commands given to him. For example in the saying "Tindih-tindih isik jauk dirik" means carefully carry yourself into attitude. ${ }^{37}$

Reme: Growing Attitudes to Care for the Environment

Reme is interpreted as an activity that expresses mutual cooperation at work. All forms of work are done together in a way that does not envy each other, does not watch each other, saling asah, saling asih, dan saling asuh. ${ }^{38}$ The term reme in Sasak tribe is often expressed in the phrase "mun pade reme selapuan becat ye selese pegawean" which means with mutual cooperation all work will quickly finish. ${ }^{39}$

Mutual cooperation as a symbol of the noble value of the legacy of Indonesia's ancestors which is recognized as providing social benefits for the community as well as bonding ties of brotherhood with each other, is increasingly felt not up to date with social reality in the present context. Consequetly, with many excuses, the member of the community gradually began to leave it and "underestimate" it by replacing it with some money. When they can not participate in mutual cooperation, they simply replaced it with some amount of money. The same thing happens with a variety of activities that involve the whole member of the community. ${ }^{40}$

Reme (mutual cooperation) is really emphasized in pondok pesantren aims to teach students in maintaining environmental cleanliness related to the interests of environmental preservation. This is also done as an effort to improve habits or culture not to aggravate environmental damage. The santri are expected to be able to improve the quality of the environment for example by avoiding littering.

${ }^{37}$ Ibid.

${ }^{38}$ Ratmaja, Bahan Ajar, 91-92.

${ }^{39}$ Hasanah, “Nilai Budaya Ungkapan,” 228.

40 Muryanti, "Revitalisasi Gotong Royong: Penguat Persaudaraan Masyarakat Muslim Di Pedesaan (Artikel Ini Dimuat Ulang Di Jurnal Dialektika Masyarakat: Jurnal Sosiologi Volume 1 No.1 2017) Https://Jurnal.Uns.Ac.Id/Dmjs/Article/View/21688," Jurnal Sosiologi Reflektif 9, no. 1 (September 8, 2016): 64, accessed June 19, 2020, https://ejournal.uinsuka.ac.id/isoshum/sosiologireflektif/article/view/1130. 
This relationship is manifested in the form of natural management for the benefit of humanbeings, both for self-interest and shared interests in moderation. ${ }^{41}$ Santri in pondok pesantren should always realize that that they are part of the environment and are caliphs on earth, then they should be preserving and managing nature rather than being a destroyer of the beauty of the environment due to human deeds themselves. The harmony of local culture with Islamic teachings in terms of maintaining environmental cleanliness is outlined in the hadith of the Prophet Muhammad as follows:

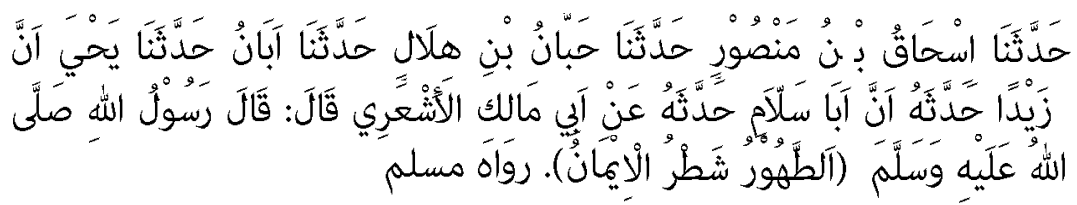

Cleanliness is part of faith. (narrated by Muslim). ${ }^{42}$

\section{Patterns of Character Education Based on Local Wisdom in Pondok Pesantren NW Selaparang Kediri, West Lombok}

Education is not only related to increasing of knowledge, but also include aspects of attitudes and behavior so that children can be pious, knowledgeable, and noble. The idea of character education programs in Indonesia is related to national education goals and based on the condition of learners at present who are experiencing character degradation..$^{43}$ El-Bassiouny said that to educate someone in the mind and not in morals is a threat to educating the public. Martin Luther King Jr proposed an idea that "intelligence plus character is the goal of true education".44

41 Ateng Rusliana, “Orang Tua dan Pendidikan Anak: Studi Kasus di Pondok Pesantren Qotrun Nada Cipayung Jaya, Depok, Jawa Barat," in Agama, Pendidikan Islam dan Tanggung Jawab Sosial Pesantren, ed. Irwan Abdullah et.al (Yogyakarta: Pustaka Pelajar, 2008), 112.

${ }^{42}$ Abū al-Ḥusayn 'Asākir al-Dīn Muslim ibn al-Ḥajjāj al-Naysābūrī, Ṣaḥ̄h Muslim (Beirut: Dār al-Kutub al-'Ilmiyah, 1991), 203.

43 Ridwan Abdullah Sani and Muhammad Kadri, Pendidikan Karakter: Mengembangkan Karakter Anak yang Islami (Jakarta: Bumi Aksara, 2016), 6.

44 Noha El- Bassiouny, Ahmed Taher, and Ehab M. Abou-Aish, "The Importance of Character Education for Tweens as Consumers: A Conceptual Model with Prospects for Future Research," Journal of Research in Character Education 6, no. 2 (July 1, 2008): 37. 
Character development through education must touch the aspect of conscience awareness of each student. Improving the character of individual students by including noble values originate from religious and cultural teachings must touch conscience awareness. ${ }^{45}$ Character is the values of human behavior related to God, oneself, fellow human beings, the environment, and actions based on religious norms, law, etiquette, culture, and customs. ${ }^{46}$ Character education is not only based on one strategy, but with a variety of strategies one of which is by way of character education based on local wisdom. Building the nation's character through local wisdom is really needed by the Indonesian people in building a better society. Fostering the character of the nation in this case can be achieved by transforming local cultural values (local wisdom) as a means of character education.

Indonesian people do not need to be confused in looking for a character education model because, in fact, the basis of character education is already owned by this nation. The basis of character education is in every noble teaching of ethnic groups and cultures in Indonesia. In short, finding the noble values that characterize the nation is not difficult. There are a lot of local wisdoms of ethnic groups can be extracted into national character. Even, the character that can be extracted and based on local wisdom can be firmly rooted, and enable the students to retain their own identity. ${ }^{47}$ Whether it is realized or not, many traditional values applied in society can be used as content of character education. These traditional values have become local wisdom, although they differ, they have very significant similarities when traditional values are synchronized with character education. ${ }^{48}$

${ }^{45}$ Muhammad Yusuf, "Pendidikan Karakter Berbasis Qurani Dan Kearifan Lokal," KARSA: Journal of Social and Islamic Culture 22, no. 1 (June 2014): 56, accessed June 19, 2020, http://ejournal.iainmadura.ac.id/index.php/karsa/ article/view/548.

46 Syamsul Kurniawan, Pendidikan Karakter: Konsepsi dan Implementasinya Secara Terpadu di Lingkungan Keluarga, sekolah, Perguruan Tinggi, dan Masyarakat (Yogyakarta: Ar-Ruzz Media, 2016), 29.

${ }^{47}$ Agus Wibowo, Pendidikan Karakter Berbasis Kearifan Lokal di Sekolah: Konsep, Strategi, dan Implementasinya (Yogyakarta: Pustaka Pelajar, 2015), 16.

48 Nuraini Asriati, "Mengembangkan Karakter Peserta Didik Berbasis Kearifan Lokal Melalui Pembelajaran Di Sekolah," Jurnal Pendidikan Sosiologi dan 
One of Islamic educational institutions that consistently teach character education based on local wisdom is pondok pesantren. In addition to deepening Islamic knowledge, pondok pesantren instill character education through the local culture of Sasak tribe that develops in the community. As a civilized society, Sasak people have good local wisdom to be transformed into the education of today's young generation. Local wisdom has been formed in the course of its long history. ${ }^{49}$ Among the examples of local wisdom rooted in the Sasak community and used as character education for santri in pondok pesantern, is reme as an attitude of caring for the environment.

The process of internalizing character education according to Thomas Lickona in Cassie B. Barlow, et al, applied through three stages: moral knowing, moral feeling, and moral action. ${ }^{50}$ Adopting the process of internalizing Thomas Lickona's character education, the cultivation of santri character education based on local wisdom in pondok pesantren NW Selaparang Kediri was also implemented through the three stages of the process of internalizing character education.

\section{Moral Knowing}

Internalization of santri character education based on local wisdom in pondok pesantren NW Selaparang Kediri is done through a moral knowing stage with the teaching process through the curriculum in madrasas by providing the local content subject entitled Gumi Sasak. The use of the curriculum in instilling knowledge about the character values of local wisdom that develops in pondok pesantren in social systems such as berembuq,

Humaniora 3, no. 2 (October 18, 2013): 110, accessed June 19, 2020, http://jurnal.untan.ac.id/index.php/JPSH/article/view/3663.

${ }^{49}$ Lalu Murdi, "Sejarah Lokal Dan Pendidikan Karakter (Tinjauan Dalam Kearifan Lokal Masyarakat Sasak Lombok)," Fajar Historia: Jurnal Ilmu Sejarah dan Pendidikan 1, no. 1 (June 9, 2017): 45, accessed March 10, 2020, http://ejournal.hamzanwadi.ac.id/index.php/fhs/article/view/580.

50 Cassie B. Barlow, Mark Jordan, and William H. Hendrix, "Character Assessment: An Examination of Leadership Levels," Journal of Business and Psychology 17, no. 4 (2003): 566, accessed February 11, 2020, https://www.jstor.org/stable/25092839. 
besemeton, base alus, tertip tapsile, and rem aimed to enable the santri to know the values of local culture as a moral force.

According to the Webster Dictionary the word curriculum means teaching material. ${ }^{51}$ In the field of education, the term curriculum, as stated by Omar Muhammad al-Toumy al-Syaibani in Abuddin Nata is a clear path taken by educators or teachers by training educated people to develop the knowledge, skills and attitudes of students. ${ }^{52}$ In the stage of developing knowledge of character education for students in pondok pesantren, character education based on local wisdom is emphasized so that students have character values such as democratic, disciplined, friendly, loving the motherland, loving peace, and caring for the environment. If all values are combined, it will become a moral inheritance which is inherited from generation to the next generations.

The education process must be pursued for the education of values as early as possible and throughout life. Educational programs and curriculum must be developed in an integrated manner in accordance with the socio-cultural background by placing moral values as the spirit. Everyday activities must place institutional leaders and educators into models who act fairly, trustworthily, and affectionately. Learning should be able to create a value education movement and oversee it continuously, both in the context of formal, informal and non-formal education. ${ }^{53}$

In justifying the curriculum based on this principle of cultural heritage, knowledge, skills, and values are seen as cultural treasures that must be passed on to the future generations in a society. Based on this understanding, the curriculum in an educational activity can be justified or accounted for if it helps students to inherit and at the same time live with the cultural

${ }^{51}$ Elvin Saputra, New Student's Webster Dictionary Inggris Indonesia-IndonesiaInggris (Tangerang: Binarupa Aksara Publisher, n.d.), 84.

52 Abuddin Nata, Ilmu Pendidikan Islam (Jakarta: Kencana Prenada Media Group, 2010), 124.

${ }^{53}$ Imam Suyitno, "Pengembangan Pendidikan Karakter Dan Budaya Bangsa Berwawasan Kearifan Lokal," Jurnal Pendidikan Karakter 2, no. 1 (2012): 8, accessed March 19, 2020, https://journal.uny.ac.id/index.php/jpka/article/view/1307. 
traditions respected by the society. ${ }^{54}$ Character development becomes a big concern for pondok pesantren. All santri activities cannot be separated from the local culture in which they live. In this way, pondok pesantren prepares its students to have cultural competence and be sensitive to all activities in the community through a curriculum implemented with the subject of local content gumi Sasak. In addition, students at pondok pesantren are also encouraged to memorize Sasak vocabulary that is posted in each hostel as a form of knowledge of Sasak language.

\section{Moral Feeling}

After the moral knowing stage, character education based on local wisdom developed at pondok pesantren required the students to have a feeling of moral awareness. This is due to the fact that, not only do children have an understanding, but the existing education system must also play an active role in supporting and conditioning the good values so that all children love these values as a virtue to be embraced involving the attributes of conscience namely, knowing and feeling obliged to do something right by means of the ability to be attracted to the goodness in life. ${ }^{55}$

\section{Moral Action}

Internalization of character education of students based on local wisdom in pondok pesantren on the stage of action is applied through the habituation model, which means the ability to do the right thing because it has been done repeatedly so that it becomes routine. ${ }^{56}$ In essence, local culture greatly influences a person's character, both in the form of actions and words. This can be developed through the direct experience of the santri of pondok pesantren I in their social and personal contexts.

\footnotetext{
${ }^{54}$ Ismail Thoib, Filsafat Pendidikan Islam: Membangun Insan Muslim Berkarakter (Mataram: LEPPIM IAIN Mataram, 2012), 126.

${ }^{55}$ Leoni Fransisca and Clara R. P. Ajisuksmo, "Keterkaitan Antara Moral Knowing, Moral Feeling, Dan Moral Behavior Pada Empat Kompetensi Dasar Guru," Jurnal Kependidikan: Penelitian Inovasi Pembelajaran 45, no. 2 (December 14, 2015): 213, accessed June 19, 2020, https://journal.uny.ac.id/index.php/ $\mathrm{jk} /$ article/view/7500.

${ }^{56}$ Barlow, Jordan, and Hendrix, “Character Assessment," 566.
} 
The development of santri character through habituation is applied in unscheduled ways such as hands-on experience practiced in the form of local wisdom that develops in pondok pesantren in using Sasak alus language and tertip tapsile attitude (polite mannered), and besemeton (brotherhood/friendship) or in a scheduled manner such as, reme together cleaning the environment with the schedule that has been determined by the board of pondok pesantren and berembuq (deliberation) which is carried out once every week on Thursday night after muhädarah (speech) activities.

In line with the above reasons, culture is not just a matter of eating, but also as something purely charged with symbol systems, like mathematics. Customs or community behavior must also be observed, because culture finds its articulation through the course of behavior or more precisely through social action. ${ }^{57}$

In solving the social problems of the community, pondok pesantren does not use development theories, but rather a movement based on good deeds as a reflection of the kyai's (leader of pondok pesantren) religious understanding and effectiveness in changing people's lifestyles. It is inseparable from the pondok pesantren education system which is always attached to the current problems faced by the community by still holding on to local traditions and Islamic teachings. These advantages are actually the tresury of this nation which, if it gets significant support from all parties, it is quite possible that pondok pesantren will be the most solutive solution for the improvement of the nation's morals when national education only prioritizes the importance of the brain rather than the heart. ${ }^{58}$

With a sense of self feeling, humanbeings want to always succeed in achieving their desires, want to be respected and valued, and want to be loved by others. That is why every human being does not want to be treated like inanimate objects. Sidi Gazalba in Khadziq said states that the superiority of humans

57 Daniel L. Pals, Seven Theories of Religion, trans. Inyiak Ridwan Munzir (Yogyakarta: IRCiSoD, 2011), 339.

${ }^{58}$ Luk Luk Nur Mufidah, “Pemikiran Gus Dur tentang Pendidikan Karakter dan Kearifan Lokal," Al-Tahrir: Jurnal Pemikiran Islam 15, no. 1 (August 25, 2015): 105, accessed February 19, 2020, http://jurnal.iainponorogo.ac.id/index.php/ tahrir/article/view/172. 
compared to other creatures is that humans have souls, from which humans finally have a culture. It is the human soul that produces culture. Here, culture is defined as a way of thinking and feeling, which expresses itself in all aspects of life from a group of human beings who form social unity, in a space and time. ${ }^{59}$

In addition to fostering the character of santri based on local wisdom carried out with habituation, pondok pesantren also emphasizes the model and exemplary approach in fostering good deeds value according to religious teachings in pondok pesantren environment. Implementation of "modeling" and "exemplary" approach, means, trying and accustoming students and the educational environment as a whole to live and uphold true values by providing a model or example. ${ }^{60}$ In this case, every ustaz (teacher) in pondok pesantren environment is emphasized as a "living example" for students. In addition, they must be prepared to be open and are willing to discuss these good values with the students. Thus, there is an intellectual internalization process for students.

The example of exemplification as character education based on local wisdom carried out by pondok pesantren was also carried out through the work of one of Sasak Islamic scholars, the late TGH. Abdul Hafidz Sulaiman who still maintains local languages in interacting with fellow students, the community and teachers. This was confirmed from various sources, everyone could feel the beauty of the language spoken by TGH. Abdul Hafidz Sulaiman when speaking to all members of his family. He never said "kamu" (you) but "pelinggih", "side", and other Sasak alus language expressions indicating his love to the children even to the santri of pondok pesantren. ${ }^{61}$ This model is a perfect disguise of the fact that the Indonesian people today need spiritual leaders who can support, protect, and guide the community to the right way, all of

${ }^{59}$ Khadziq, Islam dan Budaya Lokal: Belajar Memahami Realitas Agama dalam Masyarakat (Yogyakarta: Teras, 2009), 35.

60 Azyumardi Azra, "Pendidikan Akhlak dan Budi Pekerti Membangun kembali anak Bangsa," Mimbar Pendidikan 20, no. 1 (2001): 28-29.

${ }^{61}$ Patompo Adnan, Biografi TGH. Abdul Hafidz Sulaiman: Ilmu Bening Sebening Hati Sang Guru 1898-1983 (Lombok: Mujahid Press, 2013). 
which are very relevant to be followed and imitated by today's national leaders. ${ }^{62}$

It is obvious that the boarding school has constructed a systematic culture in carrying out daily activities. A kiai, ustadz and santri realize their respective positions so as to create a dynamic atmosphere. An ustādh as illustrated by Ema in Rudi Hartono plays a primary role as a source of information and knowledge in teaching and learning activities in madrasas. More than that, the teacher becomes a role model and a source of reference for his students. This is expressed in the popular saying that guru adalah orang yang dapat "digugu dan ditiru" meaning that a teacher should be able to be a role model. ${ }^{63}$

Religious teachings are the basic idea or foundation for its adherents. This is a phenomenological reality of a human tradition that generally applies in a society. All activities, background, and symptoms arising from human behavior are studied. Character education also refers to the words of the Prophet Muhammad that a newborn baby is in a state of nature, free from external influences. ${ }^{64}$

From the pattern of character education of students based on local wisdom, it can be identified at least seven values of character education developed in this local pesantren NW Selaparang Kediri: (1) Democracy, is a way of thinking, behaving, and acting where they value themselves as having the same rights and obligations with others. (2) Discipline, actions that show an orderly and compliant behavior with various rules and regulations. (3) Friendly, is an action that shows a sense of pleasure in talking, socializing, and cooperating with others. (4) Social Care, attitudes

62 Mukhibat, "Meneguhkan Kembali Budaya Pesantren Dalam Merajut Lokalitas, Nasionalitas, Dan Globalitas," KARSA: Journal of Social and Islamic Culture 23, no. 2 (December 1, 2015): 190, accessed March 9, 2018, http://ejournal.iainmadura.ac.id/index.php/karsa/article/view/717.

63 Rudi Hartono, "Pola Komunikasi di Pesantren: Studi tentang Model Komunikasi antara Kiai, Ustadz, dan Santri di Pondok Pesantren TMI Al-Amien Prenduan," al-Balagh: Jurnal Dakwah dan Komunikasi 1, no. 1 (June 8, 2016): 82, accessed March 2, 2020, http://ejournal.iainsurakarta.ac.id/index.php/albalagh/article/view/60.

${ }^{64}$ Hamdani Hamid and Beni Ahmad Saebani, Pendidikan Karakter Perspektif Islam (Bandung: Pustaka Setia, 2013), 62-63. 
and actions that always want to provide assistance to other people and communities in need. (5) Love Peace, attitudes, words and actions that cause other people to feel happy and safe in their presence. (6) Love the motherland, the way of thinking, acting and doing that shows loyalty, care, and high respect for the language, physical environment, social, cultural, economic, and political nation. And (7) Care for the environment, attitudes and actions that always try to prevent damage to the surrounding natural environment, and develop efforts to repair natural damage that has already occurred. ${ }^{65}$

\section{Conclusion}

Substantially, Islamic teaching has relevance to the values of local traditions of Sasak community. The forms of local wisdom developed in pondok pesantren are influenced by the activities of adat tapsile Sasak traditional procession as the principles, norms, and rules of the social system and the daily behavioral habits of santri. This is because pondok pesantren choose to live side by side with local culture which is practiced in the form of berembuq, besemeton, base alus, tertip tapsile, and reme. The pattern of character education based on local wisdom in pondok pesantren is implemented through three stages. First, moral knowing which is taught through the use of local content learning curriculum subject Gumi Sasak. Second, the stage of moral feeling, by loving the good values which are internalized through moral knowing. Third, moral action is instilled through habituation and exemplary models. The value of character education based on local wisdom that develops in pondok pesantren is, democratic attitude, discipline, friendship, social care, love for peace, love for the motherland, and care for the environment. In this context, pondok pesantren have a strategic role that successfully integrates the two. On the one hand pondok pesantren grows from the community itself, and on the other hand it is also an Islamic educational institution. This

65 Machful Indra Kurniawan, "Tri Pusat Pendidikan Sebagai Sarana Pendidikan Karakter Anak Sekolah Dasar," PEDAGOGIA: Jurnal Pendidikan 4, no. 1 (January 1, 2015): 43-44, accessed April 19, 2019, http://ojs.umsida.ac.id/ index.php/pedagogia/article/view/71. 
position enables pondok pesantren to maintain the character of the santri by integrating local culture and religion as the basis for character education.

\section{References}

Adnan, Patompo. Biografi TGH. Abdul Hafidz Sulaiman: Ilmu Bening Sebening Hati Sang Guru 1898-1983. Lombok: Mujahid Press, 2013.

Alfaqih. Strategi Pendidikan Karakter: Mempertimbangkan Tradisi Profetik. Mataram: Larispa, 2011.

Ar-Rasyid. Al-Qur'an Mushaf Terjemah Tanpa Ta'wil. Jakarta: Insan Media Pustaka, 2012.

al-Asqalān̄̄, Aḥmad ibn 'Alī Ibn Ḥajar. Bulūgh al-Marām min Adillati al-Aḥkām. Semarang: Karya Putra, n.d.

Asriati, Nuraini. "Mengembangkan Karakter Peserta Didik Berbasis Kearifan Lokal Melalui Pembelajaran Di Sekolah." Jurnal Pendidikan Sosiologi dan Humaniora 3, no. 2 (October 18, 2013). Accessed June 19, 2020. http://jurnal.untan.ac.id/ index.php/JPSH/article/view/3663.

Azhar, Lalu Muhammad. Kamus Bausastra Sasak Indonesia-Indonesia Sasak. Klaten: Macanan Jaya Cemerlang, 1997.

Azra, Azyumardi. "Pendidikan Akhlak dan Budi Pekerti Membangun kembali anak Bangsa." Mimbar Pendidikan 20, no. 1 (2001).

Badan Statistik Pemprov NTB. Nusa Tenggara Barat Dalam Angka Tahun 2015, n.d.

Baharudin, Erwan. "Kearifan Lokal, Pengetahuan Lokal Dan Degradasi Lingkungan." Forum Ilmiah 7, no. 1 (2010): 8-21. Accessed August 18, 2019. https://ejurnal.esaunggul.ac.id/ index.php/Formil/article/view/1317.

Barlow, Cassie B., Mark Jordan, and William H. Hendrix. "Character Assessment: An Examination of Leadership Levels." Journal of Business and Psychology 17, no. 4 (2003): 563584. Accessed February 11, 2020. https://www.jstor.org/ stable/25092839.

Bartholomew, John Ryan. Alif Lam Mim Kearifan Masyarakat Sasak. Translated by Imron Rosyidi. Yogyakarta: Tiara Wacana, 2001. 
Bassiouny, Noha El-, Ahmed Taher, and Ehab M. Abou-Aish. "The Importance of Character Education for Tweens as Consumers: A Conceptual Model with Prospects for Future Research." Journal of Research in Character Education 6, no. 2 (July 1, 2008): $37-62$.

Budiwanti, Erni. "Balinese Minority Versus Sasak Majority: Managing Ethno-Religious Diversity and Disputes in Western Lombok." Heritage of Nusantara: International Journal of Religious Literature and Heritage 3, no. 2 (February 12, 2015): 233-250. Accessed June 18, 2020. http://jurnallektur. kemenag.go.id/index.php/heritage/article/view/11.

Cederroth, Sven. The Spell of The Ancestors and The Power of Mekkah A Sasak Community on Lombok. Sweden: Acta Universitatis Geyheburgensis, 1981.

Faizah. "Pergulatan Teologi Salafi dalam Maenstream Keberagamaan Masyarakat Sasak." Ulumuna 16, no. 2 (December 2012): 375-402. Accessed June 17, 2019. http://ejurnal.iainmataram.ac.id/index.php/ulumuna/article/vi ew/183.

Fauziah, Nurul. "Perkembangan Pendidikan Islam Dan Kearifan Lokal Di Indonesia." AL-FURQAN 6, no. 2 (February 28, 2018): 58-66. Accessed June 11, 2019. http://ejournal.kopertais4.or.id/ sasambo/index.php/alfurqan/article/view/3267.

Fransisca, Leoni, and Clara R. P. Ajisuksmo. "Keterkaitan Antara Moral Knowing, Moral Feeling, Dan Moral Behavior Pada Empat Kompetensi Dasar Guru." Jurnal Kependidikan: Penelitian Inovasi Pembelajaran 45, no. 2 (December 14, 2015): 211-221. Accessed June 19, 2020. https://journal.uny.ac.id/ index.php/jk/article/view/7500.

Hamid, Hamdani, and Beni Ahmad Saebani. Pendidikan Karakter Perspektif Islam. Bandung: Pustaka Setia, 2013.

Hartono, Rudi. "Pola Komunikasi di Pesantren: Studi tentang Model Komunikasi antara Kiai, Ustadz, dan Santri di Pondok Pesantren TMI Al-Amien Prenduan." al-Balagh: Jurnal Dakwah dan Komunikasi 1, no. 1 (June 8, 2016): 67-100. Accessed March 2 2020. http://ejournal.iainsurakarta.ac.id/index.php/albalagh/article/view/60. 
Hasanah, Niswatul. "Nilai Budaya Ungkapan Tradisional Pergaulan Keseharian Masyarakat Sasak." Jurnal Mabasindo 1, no. 2 (2017): 221-231.

Hendri, Ezi, Ninuk Purnaningsih, and Amiruddin Saleh. "Analisis Efektivitas Musyawarah Perencanaan Pembangunan." Jurnal KMP (Jurnal Komunikasi Pembangunan) 12, no. 2 (November 10, 2014): 60-79. Accessed May 12, 2019. http://journal. ipb.ac.id/index.php/jurnalkmp/article/view/8656.

Hirzi, Azis Taufik. "Komparasi Ringkas Antara: Demokrasi Ala Barat dengan Musyawarah dalam Islam." MIMBAR: Jurnal Sosial dan Pembangunan 21, no. 2 (June 13, 2005): 250-261. Accessed June 19, 2018. https://ejournal.unisba.ac.id/ index.php/mimbar/article/view/176.

Khadziq. Islam dan Budaya Lokal: Belajar Memahami Realitas Agama dalam Masyarakat. Yogyakarta: Teras, 2009.

Kurniawan, Machful Indra. "Tri Pusat Pendidikan Sebagai Sarana Pendidikan Karakter Anak Sekolah Dasar." PEDAGOGIA: Jurnal Pendidikan 4, no. 1 (January 1, 2015): 41-49. Accessed April 19, 2019. http://ojs.umsida.ac.id/index.php/pedagogia/ article/view/71.

Kurniawan, Syamsul. Pendidikan Karakter: Konsepsi dan Implementasinya Secara Terpadu di Lingkungan Keluarga, sekolah, Perguruan Tinggi, dan Masyarakat. Yogyakarta: Ar-Ruzz Media, 2016.

Lestari. "Islam Nusantara Corak Spiritualitas Pribumi." Jurnal Elkatarie: Jurnal Ilmu Pendidikan dan Sosial 1, no. 02 (August 19, 2019): 28-41. Accessed August 29, 2019. http://ejournal.ko pertais4.or.id/sasambo/index.php/elkatarie/article/view/3610.

Milson, Andrew J., and Lisa M. Mehlig. "Elementary School Teachers' Sense of Efficacy for Character Education." The Journal of Educational Research 96, no. 1 (2002): 47-53. Accessed June 18, 2019. https://www.jstor.org/stable/27542411.

Mufidah, Luk Luk Nur. "Pemikiran Gus Dur tentang Pendidikan Karakter dan Kearifan Lokal." Al-Tahrir: Jurnal Pemikiran Islam 15, no. 1 (August 25, 2015): 91-110. Accessed February 19, 2020. http://jurnal.iainponorogo.ac.id/index.php/tahrir/article/ view/172. 
Mukhibat. "Meneguhkan Kembali Budaya Pesantren Dalam Merajut Lokalitas, Nasionalitas, Dan Globalitas." KARSA: Journal of Social and Islamic Culture 23, no. 2 (December 1, 2015): 177-192. Accessed March 9, 2018. http://ejournal. iainmadura.ac.id/index.php/karsa/article/view/717.

Murdi, Lalu. "Sejarah Lokal Dan Pendidikan Karakter (Tinjauan Dalam Kearifan Lokal Masyarakat Sasak Lombok)." Fajar Historia: Jurnal Ilmu Sejarah dan Pendidikan 1, no. 1 (June 9, 2017): 42-54. Accessed March 10, 2020. http://ejournal.hamzanwadi.ac.id/index.php/fhs/article/view/580.

Muryanti. "Revitalisasi Gotong Royong: Penguat Persaudaraan Masyarakat Muslim Di Pedesaan (Artikel Ini Dimuat Ulang Di Jurnal Dialektika Masyarakat : Jurnal Sosiologi Volume 1 No.1 2017) Https://Jurnal.Uns.Ac.Id/Dmjs/Article/View/21688." Jurnal Sosiologi Reflektif 9, no. 1 (September 8, 2016): 63-81. Accessed June 19, 2020. https://ejournal.uin-suka.ac.id/ isoshum/sosiologireflektif/article/view/1130.

Nasir, Mohamad Abdun. "Conflict, Peace, and Religious Festivals: Muslim-Hindu-Christian Relations on the Eastern Indonesian Island of Lombok." Interreligious Studies and Intercultural Theology 4, no. 1 (April 14, 2020): 102-123. Accessed April 18, 2020. http://ojs3.equinoxpub.com/ISIT/article/view/17625.

Nata, Abuddin. Ilmu Pendidikan Islam. Jakarta: Kencana Prenada Media Group, 2010.

al-Naysābūrī, Abū al-Ḥusayn 'Asākir al-Dīn Muslim ibn al-Ḥajjāj. Șahīh Muslim. Beirut: Dār al-Kutub al-'Ilmiyah, 1991.

Pala, Aynur. "The Need for Character Education." International Journal of Social Sciences and Humanity Studies 3, no. 2 (2011): 132. http://www.sobiad.org/eJOURNALS/journal_IJSS/arhieves/ 2011_2/aynur_pala.pdf.

Pals, Daniel L. Seven Theories of Religion. Translated by Inyiak Ridwan Munzir. Yogyakarta: IRCiSoD, 2011.

Ratmaja, Lalu. Bahan Ajar Muatan Lokal Budaya Sasak untuk SMP/MTs Kelas IX. Lombok: Gumi Sasak, 2011.

- - - Bahan Ajar Muatan Lokal Budaya Sasak untuk SMP/MTs Kelas VIII. Lombok: Gumi Sasak, 2011.

Rusliana, Ateng. “Orang Tua dan Pendidikan Anak: Studi Kasus di Pondok Pesantren Qotrun Nada Cipayung Jaya, Depok, 
Jawa Barat." In Agama, Pendidikan Islam dan Tanggung Jawab Sosial Pesantren, edited by Irwan Abdullah et.al. Yogyakarta: Pustaka Pelajar, 2008.

Sani, Ridwan Abdullah, and Muhammad Kadri. Pendidikan Karakter: Mengembangkan Karakter Anak yang Islami. Jakarta: Bumi Aksara, 2016.

Saparudin. "Gerakan Keagamaan dan Peta Ideologis Pendidikan Islam di Lombok." MIQOT: Jurnal Ilmu-ilmu Keislaman 42, no. 1 (August 25, 2018): 220-241. Accessed June 18, 2020. http://jurnalmiqotojs.uinsu.ac.id/index.php/jurnalmiqot/article /view/506.

- - - "Salafism, State Recognition and Local Tension: New Trends in Islamic Education in Lombok." Ulumuna 21, no. 1 (June 30, 2017): 81-107. Accessed June 10, 2019. https://ulumuna.or.id/index.php/ujis/article/view/68.

Saparudin, Saparudin. "Salafism, State Recognition and Local Tension: New Trends in Islamic Education in Lombok." Ulumuna 21, no. 1 (June 30, 2017): 81-107. Accessed June 18, 2020. https://ulumuna.or.id/index.php/ujis/article/view/68.

Saputra, Elvin. New Student's Webster Dictionary Inggris IndonesiaIndonesia-Inggris. Tangerang: Binarupa Aksara Publisher, n.d.

Sartini, Ni Wayan; "Bahasa Pergaulan Remaja: Analisis Fonologi Generatif." Mozaik: Jurnal Ilmu Humaniora 12, no. 2 (December 2012): 122-132.

Setiahati. "S2 (Bukti Cinta Suku Sasak)." Pesona Budaya Pulau Seribu Masjid, December 21, 2017. Accessed March 23, 2020. http://setia28.blogspot.com/2017/12/s2-bukti-cinta-sukusasak.html.

Sirulhaq, Ahmad. "Konsep Dasar Standarisasi Bahasa Sasak: Ke Arah Kebijakan Pembelajaran dan Pemertahanan Bahasa Sasak di Lombok." 173-177. Hotel Pandanaran Semarang, 2011. Accessed September 19, 2019. http://lamas.undip.ac.id.

Suyitno, Imam. "Pengembangan Pendidikan Karakter Dan Budaya Bangsa Berwawasan Kearifan Lokal." Jurnal Pendidikan Karakter 2, no. 1 (2012): 1-13. Accessed March 19, 2020. https://journal.uny.ac.id/index.php/jpka/article/view/1307.

Thoib, Ismail. Filsafat Pendidikan Islam: Membangun Insan Muslim Berkarakter. Mataram: LEPPIM IAIN Mataram, 2012. 
Wibowo, Agus. Pendidikan Karakter Berbasis Kearifan Lokal di Sekolah: Konsep, Strategi, dan Implementasinya. Yogyakarta: Pustaka Pelajar, 2015.

Wilian, Sudirman. "Tingkat Tutur dalam Bahasa Sasak dan Bahasa Jawa." Wacana 8, no. 1 (April 1, 2006): 32-53. Accessed June 19, 2019. http://wacana.ui.ac.id/index.php/wjhi/article/view/245.

Yudarta, I. Gede, and I. Nyoman Pasek. "Revitalisasi Musik Tradisional Prosesi Adat Sasak Sebagai Identitas Budaya Sasak." Segara Widya: Jurnal Hasil Penelitian dan Pengabdian Masyarakat Institut Seni Indonesia Denpasar 3 (October 17, 2015): 367-375. Accessed May 18, 2019. https://jurnal.isidps.ac.id/index.php/segarawidya/article/view/175.

Yusuf, Muhammad. "Pendidikan Karakter Berbasis Qurani Dan Kearifan Lokal." KARSA: Journal of Social and Islamic Culture 22, no. 1 (June 2014): 52-65. Accessed June 19, 2020. http://ejournal.iainmadura.ac.id/index.php/karsa/article/view/ 548. 